\title{
TRTaKadeмi
}

ISSN 2149-9446 | Cilt 07 | Sayı 14 | Ocak 2022 | Sosyal Medya

\section{Türk TikTokerların İçerik Paylaşım Pratikleri Üzerine Nicel Bir Araştırma}

\section{Mehmet Sinan TAM ${ }^{*}$}

\begin{abstract}
Öz
Çin'de 2016 yılında Douyin, Çin dışında ise TikTok adıyla Ağustos 2018 yılında piyasa sürülen TikTok uygulaması, kısa bir sürede tüm dünyaya yayılarak milyarlarca kullanıcı tarafindan kullanılan bir sosyal medya uygulamasına dönüştü. ABD başta olmak üzere birçok ülkede en çok indirilen sosyal medya uygulaması olan TikTok, 2021 yılında Türkiye'de en çok kullanılan üçüncü sosyal medya uygulaması konumuna sahip olmuştur. TikTok ve Türk TikTokerları konu edinen bu araştırmada, Türk TikTokerların içerik paylaşım pratiklerini ortaya çıkartmayı amaçlamıştır. En çok takip edilen 10 Türk TikToker hesabının örneklem alındığı bu çalışmada; 2021 yılııın ilk dokuz ayı içerisinde en çok paylaşımın yapıldığı ağustos ayındaki video içerikleri (410), nicel içerik analizi yöntemince kodlanmıştır. Araştırma sonucunda; Türk TikTokerların daha çok sosyal medyadaki akımları içeriklerine uyarlayarak $(\% 50,24)$ kendilerini evde $(\% 40)$ tek başına kamera önüne çıkartan içerikler hazırladığı $(\% 46,1)$, bu içerikleri herhangi bir kırpma yapmadan Türkçe $(\% 39,76)$ veya İngilizce $(\% 35,12)$ dilinde popüler olan müziklerle $(\% 43,66)$ veya pleybekle $(\% 20,49)$ kurguladığı tespit edilmiştir. Türk TikTokerların TikTok'un çıkış noktası olan Musical.ly uygulaması perspektifiyle platformu deneyimlediği söylenebilir. Çalışma Türk kültürü özelinde TikTokerların paylaşım pratiklerini ortaya koyarak alanda herhangi bir çalışma bulunmayan bu konu hakkında önemli bir açığı gidermektedir.
\end{abstract}

Anahtar Kelimeler: TikTok, TikTokerlar, Türkiye, Sosyal Medya Fenomenleri, Sosyal Medya

*Dr. Öğr. Üyesi., Trabzon Üniversitesi Vakfikebir Meslek Yüksekokulu Pazarlama ve Reklamcllık Bölümü mehmetsinantam@gmail.com

Tam, M. S. (2022). Türk TikTokerların İçerik Paylaşım Pratikleri Üzerine Nicel Bir Araştırma. TRT Akademi, 7 (14), 182-211. DOI: $10.37679 /$ trta.1008427

\section{Araştırma Makalesi}

Geliş Tarihi: 13.10.2021

Revizyon Tarihi: 29.11.2021

Kabul Tarihi: 14.01.2022 


\title{
TRTakadeмi
}

ISSN 2149-9446 | Volume 07 | Issue 14 | January 2022 | Social Media

\section{A Quantitative Research on Content Sharing Practices of Turkish TikTokers}

\author{
Mehmet Sinan TAM
}

\begin{abstract}
The TikTok application, which was launched in China in 2016 as Douyin and outside of China as TikTok in August 2018, spread all over the world in a short time and turned into a social media application used by billions of users. TikTok, which is the most downloaded social media application in many countries, especially in the USA, has become the third most used social media application in Turkey in 2021. In this research, which focuses on TikTok and Turkish TikTokers; aims to reveal the content sharing practices of Turkish TikTokers. In this study, where the most followed 10 Turkish TikToker accounts were taken as a sample; in the first nine months of 2021, the most shared video contents in August (410) were coded by the quantitative content analysis method. As a result of the research; It is stated that Turkish TikTokers mostly adapt the trends in social media to their content and prepare content that puts them in front of the camera alone (40\%) at home (50.24\%), without clipping these content in Turkish (39.76\%) or English (35.12\%). It has been determined that he edited it with popular music in the language (43.66\%) or with playback (20.49\%). It can be said that Turkish TikTokers have experienced the platform with the perspective of the Musical.ly application, which is the starting point of TikTok. The study, by revealing the sharing practices of TikTokers in Turkish culture, fills an important gap on this subject, which has not been studied in the field.
\end{abstract}

Keywords: TikTok, TikTokers, Turkey, Social Media Influencers, Social Media 


\section{Giriş}

Son on yılda ortaya çıkan sosyal medya platformlarıyla TikTok karşılaştıııldı̆ında, TikTok diğer platformlara kıyasla oldukça kısa bir süre zarfinda neredeyse tüm dünyada en çok indirilen sosyal medya uygulaması olmuştur (Domingues vd. 2020, s. 2). TikTok'ta kullanıılar en az birkaç saniye ile en fazla üç dakikalık video içerikleri üretmektedir (Qiyang ve Heekyoung, 2019, s. 114). Kısa video içeriklerinin paylaşıldığı mobil bir uygulama olan TikTok'ta kullanıcılar; eğlenme, gündelik yaşamdan kaçma, yeni insanlar tanıma, arkadaş edinme, video arşivleme, kendini ifade etme, başkalarını dikizleme, diğer kullanıcıların içeriklerine etkileşimde bulunma, sosyalleşme ve sosyal ağda kendini görünür kılma motivasyonlarıyla bu mecraya katılmaktadır (Ma vd. 2019, s. 5; Zhang, 2020, s. 224; Omar ve Dequan, 2020, s. 128). Bu motivasyonlarla TikTok'u deneyimleyen kullanıcıların diğer sosyal medya platformlarıyla benzer güdüleyicilerle TikTok’a katıldıkları söylenebilir.

Kullanıııların TikTok'a katılmasında üç büyük etken belirleyici olmaktadır. Bunlardan ilki; yemek yapma, dans etme veya pratik bilgileri öğretme/öğrenme arzusu, ikincisi; zengin içeriklerle izleyicilerin kendini eğlendirmesi, son olarak, sıradan bir kullanıcı deneyiminden ziyade TikTok'un bir şöhret ve fenomen olma kapısı olarak görülmesidir (Liqian, 2018, s. 8-9). Bu bağlamda, TikTok'a içerik yükleyen çoğu hesabın nihai hedefi; herkesçe bilinen bir TikToker kişiliğine/hesabına dönüşerek bu mecra üzerinden gelir elde etmek olduğu rahatlıkla ifade edilebilir. TikTok'a kullanıcıların katılımını belirleyen bu etmenlerin yanı sıra platformun kullanıcı kaybetmesine etki eden dezavantajı yönler de bulunmaktadır. TikTok içeriklerinin herkes tarafindan kolayca üretilebilecek homojen yapıda kalması, kullanıcıların estetik kaygılarla içeriklerini üretmemesi ve TikTok kullanıcılarının daha çok 20-29 yaş aralığındaki kişilerden oluşmasından ötürü pazar hâkimiyetinin bu yaş kitlesinin ilgi ve memnuniyetiyle doğrudan entegreli olması platformun ilk bakışta göze çarpan dezavantajlı yönlerini oluşturmaktadır (Yang vd. 2019, s. 342). Müzik kökenli bir uygulamadan (Musical.ly) gelen TikTok'ta sıklıkla bu bağlamda içerikler paylaşılmaktadır. Fakat TikTok'ta müzik ve koreografi görüntüsü altında bilhassa kadın kullanıcıların teşhir ve müstehcenliği öne çıkartan içerikleri çok sık bir biçimde paylaştğ̆ı bulgulanmıştır (Vizcaíno-Verdú ve Tirocchi, 2021, s. 7). TikTok için getirilen en sık eleştiriler işte bu noktada olmaktadır. Müstehcenlik ve veri gizliliği sorunu, TikTok'un son yıllarda $A B D$ başta olmak üzere birçok ülkede ya kısıtlanmasına ya da yasaklanmasına neden olmuştur (Neyaz vd., 2020, s. 56; Siddiqui, 2021, s. 9-10). TikTok için getirilen bu kısıtlama/erişim engelleri, ülkemizde; müstehcenlik, ahlaki dejenarasyon ve bağımlılık başıkları altında son yıllarda çeşitli platformlarda dile getirilmektedir. Tüm bunlar dışında TikTok 
hakkında her geçen gün yükselen şüpheler, içeriklerinin kültürel bir değer olarak kabul görülmemesi, Z kuşağı dışındaki diğer kuşakların TikTok’a yönelik takındığı negatif bakış açısı ve içeriklerinin sindirilmeden hızlıca tüketmeye olanak tanıyan arayüzü de TikTok için ifade edilebilecek dezavantajlı yönlerdir.

Sosyal medya platformlarında bilinir hâlen kişiler için Senft (2008) mikro ünlüler kavramını kullanmıştır. Sonraki yıllarda bu kişiliklere sosyal medya etkileyicileri denilmiştir. Ülkemizde sosyal medya etkileyicilerinden ziyade "Sosyal Medya Fenomeni" yakıştırması daha çok kullanılmaktadır (Tam, 2020, s. 1328) Günümüzde ise mecraya göre bir farklılığa gidilerek sanal kişiliklerin popüler olduğu mecraya göre bir niteleme yapılmaktadır (Youtuber, Instagramer, Viner vb.). TikTok'ta isim, görüntü, yüz, söylem veya eylemlerini diğer kullanıcıların hafizalarında yer edindirmeyi başaran sanal kişiliklere TikToker denilmektedir. TikTokerlar, kendilerini ve takipçilerini eğlendirmek için pleybek veya dans içeriklerine filtreler uygulayarak izleyicilerine dijital içerikler üretmektedir. TikTokerlar bu içerikleri; sosyal kabul, kendilerini rahat hissetme ve tatmin olma gibi nedenlerle yapıp paylaşmaktadır (Lodice ve Papapicco, 2021, s. 11). TikTokerların bu içerikleri neden ürettiğinin yanı sıra "ne paylaştı̆̆ı" sorusu da burada öne çıkmaktadır. Bu perspektifle çalışmada; en çok takip edilen 10 Türk TikToker hesabının en fazla paylaşım yaptığı Ağustos 2021 ayı içindeki tüm paylaşımları (410) nicel içerik analizi yöntemince incelenmiştir. Belirlenen araştırma sorularıyla; Türk TikTokerların kim olduğu, ne paylaştı̆̆ı, etkileşim performanslarının nasıl olduğu, videolarını nerede çektiği, hangi dille daha çok içeriklerini seslendirdiği ve video içeriklerinde kimlerin bulunduğu sorularına cevap aranmaya çalışılmıştır.

TikTok hakkında yapılan akademik çalışmaların daha çok yurt dışı özelinde gerçekleştirildiği, ülkemizde yapılan çalışmalarınsa çok sınırlı bir düzeyde kaldığı gözlemlenmiştir. Ülkemizde TikTok konusunda yapılan çalışmalarda; TikTok'ta yayınlanan reklam ve sponsorluk faaliyetlerinin tüketici davranışları üzerindeki rolü, TikTok akımları özelinde TikTok hakkında Twitter kullanıcılarının getirdiği eleştiriler, influencer pazarlama, TikTok'ta sosyal normlar ve değerlerde yaşanan değişimler ve kullanıcıların söz konusu platformdaki izlenim yönetimlerine odaklanılmıştır (Yıldız, 2019; Uğurhan ve Yaşar, 2021; Akpınar, 2021; Şeker, 2021; Gedikoğlu ve Atalay, 2021). İlgili çalışmaların iletişim bilimleri alanında yoğunlaşthğı görülmektedir. Yapılan bu çalışmanın önceki yapılan araştırmalardan en önemli farkı; TikTok'ta popüler olan Türk TikTokerların kim olduğu ve ne paylaştığını keşfetmesi olmuştur. Alanyazında bu bağlamda herhangi bir çalışmanın bulunmaması, araştırmanın bu noktada literatürde önemli bir boşluğu dolduracak öneme sahip olduğunu göstermektedir. 
Çalışmanın literatür kısmının ilk bölümünde; TikTok'un piyasaya çıkışı, dünyada ve Türkiye'de trend olma durumu, mecrayı kullanma motivasyonları, TikTok'un ülkeler bazında yaşadığı veya uyguladığı yasak ve kısıtlamalara ve diğer sosyal medya uygulamalarıyla olan farklılıklarına değinilmiştir. İkinci bölümde ise TikToker kavramı, ülkemizde en çok takip edilen TikTok hesaplarının hangileri olduğu, bu hesapların etkileşim oranları ve 2021 yılının ilk dokuz ayı içerisinde Türk TikTokerların yaptı̆̆ paylaşım sayılarına odaklanılmıştır.

\section{Kısa Video Paylaşım Uygulaması TikTok}

Gününüzü güzelleştirin (Make Your Day) sloganı ve eğlendirme misyonuyla kulIanıcılarına seslenen TikTok'un; Los Angeles, New York, Londra, Paris, Berlin, Dubai, Mumbai, Singapur, Jakarta, Seoul ve Tokyo'da ofisleri bulunmaktadır (TikTok, 2021). TikTok, 1 Ekim 2020'de sosyal medya yasası olarak bilinen düzenleme çerçevesi doğrultusunda 2021'in başlarında Türkiye'de temsilcilik açmıştır (TRT Haber, 2021). TikTok'ta kullanıcıların içerik üretebilmesi için ilk önce bir hesap açması gerekmektedir. Kullanıcı adı almaksızın TikTok kullanmak, kişiye oldukça sınırlı imkânlar tanımaktadır. TikTok mobil uygulaması hem Play hem de App mağazasından indirilmektedir. Kullanıcılar telefon dışında ayrıca bilgisayar ve tablet aracılığıyla da TikTok'a erişim sağlayabilmektedir.

Kısa video paylaşma platformu alanında neredeyse tüm dünyada kullanılan TikTok, bu alanda liderlik iddiasıyla son yıllarda kendini konumlandırmaktadır (Craig vd. 2021, s. 168). TikTok'un hikâyesi Alex Zhu ve Luyu Yang tarafindan Çin'in Shangay kentinde kurulan 'Musical.ly' uygulamasına dayanmaktadır. Musical.ly'nin kısa bir zaman içerisinde milyonlarca kişinin kullandığı bir platforma dönüşmesi, Pekin merkezli ByteDance'yi her geçen gün gittikçe popüler olan bu uygulamayı satın almaya itmiştir. ByteDance firması Musical.ly'i Çin'de 2016 yılında Douyin (?? ?), Çin dışında ise TikTok ismiyle Ağustos 2018 yılında kısa video paylaşım mant-ğıyla piyasaya sürmüştür (Shengjie, 2021, s. 8). TikTok'un her bir ülke için tasarladığı mikro farklılık politikası, bu platformun kısa bir zamanda tüm dünyada kullanıcı sayısını hızla arttırmasına katkı sağlamıştır (Kaye vd., 2021, s. 245). TikTok'un başarısında, kovid-19 pandemisiyle birlikte dijital tüketicilerin boş zamanlarını değerlendirmek adına bu platformda hesap açması da etkili olmuştur (Unni ve Weinstein, 2021, s. 868). Bu bağlamda 2019'un sonunda patlak veren kovid-19 sağlık krizinin gerek Türkiye'de gerekse yurt dışında TikTok'a aktif kullanıcı sayısını arttırmada büyük bir firsat getirdiği söylenebilir.

Eylül 2021 verilerine göre TikTok; Facebook, YouTube, Snapchat ve Instagram gibi dev ağları başta Amerika Birleşik Devletleri (ABD) olmak üzere, birçok ülkede ge- 
ride bırakmayı başarmıştır. TikTok Türkiye'de ise Instagram ve Snapchat'ten sonra en çok kullanılan üçüncü mobil uygulama konumundadır (Appannie, 2021). We Are Social'in 2021 raporuna göre; TikTok Türkiye'deki kullanıcılar aylık ortalama 14 saatini bu platformda geçirmektedir (Wearesocial, 2021). TikTok'un piyasa serüveni kısa olmasına rağmen görmüş olduğu rağbet her geçen gün devam etmektedir. Tıpkı gelişmiş ülkelerde olduğu gibi TikTok'un Türkiye'de de yakın zaman içerisinde en çok kullanılan sosyal medya uygulaması olacağı öngörülmektedir. Nitekim Google arama trendlerine bakıldığında; Türkiye'de her geçen yıl TikTok ile ilgili aramaların arttı̆ı gözlemlenmiştir (GoogleTrends, 2021). Kullanıcıların arama dönemlerine bakıldığında; 2018'de "TikTok nedir, TikTok videoları, TikTok nasıl indirilir", 2019'da "TikTok şarkıları, TikTok beğeni ve takipçi hileler"i, 2020'de "TikTok kahvesi, cellat36, TikTok para hesaplama" ve 2021'in ilk dokuz ayında "sss.TikTok (video indirme), TikTok board ve TikTok yazısız video indirme" aramaları ön plana çıkmıştır. Türkiye'de TikTok hakkında yapılan bu aramalara bakıldığında; 2018 yılında mecranın ismi hakkında internette aramalar yapıldığı, kullanıcıların uygulamanın teknik anlamda nası indirileceği ve kullanılacağını merak ettiği ve TikTok'ta paylaşılan içeriklerin Google tarayıcısı üzerinden izleme eğiliminin olduğu görülmektedir. Sonraki yılda; kullanıcılar teknik sorunlardan çok profil bilgilerine yapay düzenlemeleri nasıl yapacaklarına ve uygulamada paylaşılan müzikleri Google'da aratmıştır. 2020 yılında TikTokerlar, mecra üzerinden gelir elde etme ve akıma dönüşen içerikler hakkında aramalar yapılmıştır. 2021'in ilk dokuz ayında ise kullanıcılar; uygulamadaki içerikleri nasıl telefon/bilgisayarlarına indireceklerine dair teknik bilgilere ve TikTok Türkiye'de trend olan içeriklere Google tarayıcısı üzerinden bakmıştır.

TikTok, sahip olduğu özellikler ile diğer sosyal medya platformlarından kendini ayrıştırmaktadır. TikTok'u diğer sosyal medya platformlarından farklı kılan yönleri şu şekilde sıralanabilir (Scherr ve Wang, 2021; Serrano vd., 2020; Sun vd., 2020; Anderson, 2020): Kullanıcılar arasında daha yüksek düzeyde etkileşim ortamı sağlaması, birçok interaktif özelliği bünyesinde barındırması, kullanıcılarını içerikleri sadece bir kere ve olabildiğince hızlı bir biçimde tüketmeye odaklaması, kaynaktan hedefe giden mesajın müzik kurgusuyla gerçekleştirmesi, kullanıcıya izlemesi için önerilen videolar platforma yükleme sırasına göre değil; ülke içinde en çok izlenme, beğeni ve yorum yapılma durumuyla ilintili bir algoritmayla sunması, TikTok kullanıcılarının bizatihi kendisi de paylaşılan bir içeriğin konusu veya malzemesi olabilmesi, Facebook, Twitter ve Instagram vb. uygulamaların çalışma mantı̆̆ daha çok arkadaş eksenliyken, TikTok ise tıpkı YouTube gibi daha halka açık bir yapıda hizmet vermesi ve TikTok'ta içerik bulma ve onu paylaşmanın 
oldukça basit düzeyde kalması Tiktok'u diğer platformlardan farklı kılmaktadır. Tüm bu farklılıklara ek olarak şunlar da ilave edilebilir: Videoların belirli bir süre ile sınırlandırarak (3 dk.) tüketim kolaylığı sunması, karşılıklı mesajlaşmanın kullanıcılar tarafindan sınırlandırılması veya engellenmesi, yazılı metinlerin sadece video veya fotoğraf üzerinden paylaşılması, kullanıcıların topluluk kurallarını ihlal eden içerikleri veya hesapları rapor etmesinin oldukça kolay kılması, paylaşılan içerikleri telefona/bilgisayara kolaylıkla indirmeye olanak tanıması, video kurgulamada profesyonel filtreler ve video içerisinde istenilen herhangi bir yere yazı ekletebilme olanağını sağlaması, bilgisayar üzerinden erişildiğinde yeni bir sekme ya da masaüstüne gelindiğinde videoyu duraklatması ve diğer sosyal medya uygulamalarına ait linklere daha kolay bir şekilde erişim sağlaması TikTok'un diğer sosyal medya platformlarından ayrılan önemli farklılıkları olarak sıralanabilir. Öte yandan, popüler olan sosyal medya mecraları arasında ABD veya Bat menşeli olmayan bir uygulama olması da yine uygulamayı çıkış yeri anlamında farklı kılmaktadır.

TikTok'ta kullanıcılar sıklıkla dans, mizah, pleybek ve bireysel yeteneklerini sergileyen videolar paylaşmaktadır (Weimann ve Masri, 2020, s. 3). Çin'de Douyin olarak bilinen TikTok; kullanıcılarına uygulamaya katılma, içerik üretme veya üretilenleri tüketme olanağı sunmaktadır. TikTok kullanıcılarına içerikleri paylaşma, beğenme, yorumlama, kullanıcılarla mesajlaşma ve canlı yayın yapabilme imkânlarını ücretsiz sunmaktadır. TikTok'ta video akışı, kullanıcıların sayfasında bulunan iki ayrı bölümde gerçekleşmektedir. Sol bölümdeki akışta takip edilen hesaplardaki içerikler görülürken sağ taraftaki bölmede ise yerel düzeyde popüler olan videolar ile canlı yayınlar kullanıcıların ilgisine sunulmaktadır. Uygulama her ne kadar ücretsiz olsa bile bazı canlı yayınlara erişmek veya canlı yayını gerçekleştiren kullanıcılara özel olarak tasarlanmış emojiler göndermek için belirli oranda TikTok jetonlarının kullanıcının hesabında bulunması gerekmektedir. Bu jetonlar; kredi veya banka kart, mobil hat faturası, Google Play hediye kart veya promosyon kodu kullanılarak TikTok hesabına yüklenebilmektedir. TikTok içerik üreticileri, gerçekleştirdikleri canlı yayınlarda maddi kazanç elde edebilmek için bu jetonları izleyicisinden sürekli olarak talep ettiği gözlemlenmiştir.

TikTok'un kullanıcılarına sunduğu özellikler bilhassa Z kuşağının dikkatini daha çok çekmektedir. Bu nedenle platformu kullanan kesimin daha çok Z kuşağı olduğu göze çarpmaktadır (Bangs, 2020, s. 7). Bu platformu kullanan bireyler, farklı motivasyonlar bağlamında TikTok'u deneyimlemektedir. Kullanıcılar; eğlenme, reel yaşamdan kaçma, sosyal etkileşim, video arşivleme, kendilerini ifade etme ve diğer kullanıcıları dikizleme motivasyonlarıyla bu mecraya katılmaktadır 
(Zhang, 2020, s. 224; Omar ve Dequan, 2020, s. 128). Z kuşağının var olan etkinlikleri kaçırma korkusu (FoMo), sosyal medyayla sosyalizasyonu sağlama ve kişilik/kimliğini görünür kılma dürtüleri de TikTok'ta hesap açma isteğinde belirleyici olmaktadır (Katz vd., 2021, s. 165). Kullanıcıları bu mecraya çeken diğer noktalarsa TikTok içeriklerini üretmede uygulamanın kullanıcılarına tanıdığı kolaylık, akıllı telefonların video kurgulamadaki gelişmiş özellikleri, geleneksel medyanın tektipleşmesi ve sosyal çevre etkisi, TikTok'un hem kullanıcı sayısını hem de içerik üretimine katkı sağlamaktadır. Ayrıca TikTok'ta içerik üretme, YouTube ve Twitch gibi popüler video uygulamalarından daha kolaydır. Bu kolaylığı sağlayan ana etmen, video sürelerinin kısa olması ve konuşulmadan sadece pleybek veya taklit içeren paylaşımların bile kullanıcılar tarafindan izlenilebilmesidir. Nitekim TikTok'ta çok da profesyonel ve estetik olmayan fakat ilginç ve viral olan içerikler özellikle kullanıcılar tarafindan rağbet görmektedir (Wang, 2020, s. 2). Bu durum, söz konusu mecraya hem yeni kullanıcılar kattğı hem de bu kullanıcıların yeni viral içerikler üretmeye teşvik ettiği düşünülmektedir.

TikTok popülerliği kadar erişim yasaklarıyla da sıkça gündeme gelmektedir. Endonezya, Pakistan, Bangladeş ve Hindistan TikTok'a erişim yasağı uygulayan ülkeler olmuştur. Bu ülkeler dışında ABD'de de TikTok'un yasaklanması gündeme gelmiş fakat mahkeme tarafindan verilen kararla söz konusu yasak Donald Trump yönetimi tarafindan gerçekleştirilememiştir (Supak, 2021, s. 533-534). ABD, İsrail ve Avustralya'nın başını çektiği bazı ülkelerde ise özellikle güvenlik ve istihbarat birimlerinde çalışanların TikTok kullanımına ilişkin sınırlandırmalar getirmiştir (Segev, 2020, s. 3). TikTok'a erişim yasağı uygulayan ve getirmeye çalışan bu ülkeler; ahlaksız ve müstehcenlik, kullanıcı bilgilerinin gizliliğini ihlal etme, ulusal güvenlik, uygunsuz içerikler, çocukları ve gençleri ahlaki ve sosyal bozulmadan kurtarma başlıkları çerçevesinde erişim engeli/kısıtlaması getirmiştir. Erişim yasağı getirilen ülkelerde, TikTok kullanıcı kaybı yaşamayıp yeni kullanıcılar kazanmıştır. TikTok'a getirilen veya getirilmeye çalışılan erişim yasağının yanı sıra TikTok'un gönüllü olarak çekildiği bölgeler de (Hong Kong) bulunmaktadır. Söz konusu yasaklamalar sadece toplum sağlığı bağlamında değil aynı zamanda taraf devletlerin Çin Halk Cumhuriyeti ile yaşadıkları politik gerilimler nedeniyle de uygulandığı söylenebilir.

Ülkemizde de son yıllarda Twitter başta olmak üzere, birçok sosyal medya platformunda TikTok'un yasaklanması gündeme getirilmektedir (Akpınar, 2021). Bu tür gündemler, çocuk ve gençlerin ahlaki yozlaşması ve müstehcenlik çerçevesinde yoğunluk kazanmaktadır. Kamuoyu tarafindan dile getirilen yasaklamaların yanı sıra TikTok'un kendisi de bazı paylaşımlara otosansür uygulamıştır. 
Ülkemizdeki bu sansürler; PKK propagandası, alkol tüketimi ve İslami olmayan dini obje ve tanrılar başlıklarında gerçekleşmiştir (Yiming, 2020). Her ne kadar gerçekleştirilen bu otosansürler ülkenin politikalarıyla örtüşecek şekilde yapılsa da hâlen söz konusu mecra içerisinde farklı ad ve içeriklere sahip hesaplar tarafindan terör örgütü propagandası yapılmaktadır.

Toplumda TikTok hakkında en çok vurgu yapılan konu; bu mecranın yavaş da olsa çocukları ve gençleri ahlaki bakımdan zehirlemesidir (Shengjie, 2021, s. 10). TikTok'un genç dimağları zehirlemesinin yanında son yıllarda dünya çapında içerik üretme adına yaşanan ölümler de TikTok'un meşruiyetini bir kez daha sorgulamaya neden olmuştur. Ülkemizde TikTok kaynaklı ilk ölüm, Mardin'den İstanbul’a gelen 23 yaşındaki genç bir kızın güneşin batışını çekmek için çıktığı çatıdan aşağıya düşmesi sonucu meydana gelmiştir (Hürriyet, 2021). Hatta yurt dışında TikTok canlı yayınında intihar eden TikTokerlar bile olmuştur (Haber Global, 2021). TikTok kullanıcılarının kendi içinde yaptıkları meydan okumalar (challenge), ciddi yaralanmalara, intiharlara ve ölümle sonuçlanan kazaların yaşanmasına neden olmaktadır. Bu nedenle uzmanlar, ebeveynlere TikTok kullanmak isteyen çocuklarına bazı sorular sorulmasını tavsiye etmektedir. Bu doğrultuda ebeveynlerin çocuklarına; TikTok'u neden kullanmak istediği, arkadaş çevresinin TikTok'u nasıl kullandığı, TikTok'un tehlikeli yanlarını bilinip bilinmediği, uygulamayı kullanırken kendini nası koruyacağı, kullanıcıların bilmedikleri yabancılara para karşılığında neden emojiler gönderdiği ve kendi çocuğuna sen de böyle bir şey yapacak mısın sorularının sorulmasını önermektedir (Lord vd., 2019, s. 8).

\section{Yeni Bir Influencer/Etkileyici Tipi Olarak TikTokerlar}

Sosyal medya uygulamalarının hayatımıza bu denli sirayet etmediği yıllarda kamuoyunda bilinen kişiler, geleneksel medya araçlarında ülke gündeminde sıkça adı geçen sanatçı, sporcu veya politikacılar olmaktaydı. Sosyal medya platformlarının ortaya çıktı̆̆ ilk yıllarda ise burada bulunan kişilerden ziyade mecraların bizatihi kendisi daha fazla öne çıkmaktaydı. Örneğin blog yazma üzerine birçok blogger çıksa da günümüz etkileyicileri kadar bu kişiler bilinir olmamıştır. Son yıllarda ise sosyal medyadaki sanal kişilikler mecranın önüne geçerek ağın dinamizmine önemli katkılarda bulunmuştur. Bu kişiler; sosyal medyada yayınlar yapan, belirli bir takipçi kitlesi bulunan ve sosyal medya kullanıcılarının jargonunda yer edinmiş şahsiyetlerdir. Sosyal medya etkileyicileri olarak ifade edilen bu şahıslar; sosyal medya paylaşım kültürü içerisinde kendini takipçileri önünde kanıtlamış, sıradan fakat sosyal medyada ünlenmiş kişiler şeklinde de ifade edilebilir. Öyle ki sosyal medya kültürü içerisindeki bu tanınmışlık, kişileri zaman içerisinde deyim 
yerindeyse bir kanaat önderi rolüne de dönüştürmüştür (Tam, 2020). Bu bağlamda, yaşadığımız dönemde sosyal medya platformların kendisi kadar bu platformlarda içerik üretenler de ciddi düzeyde toplumun içine sirayet etmiştir.

Kısa video uygulaması olan TikTok'ta içerik paylaşan kullanıcılara TikToker denilmektedir (Lutfiah ve Sudarwati, 2021, s. 369). Fakat TikToker kavramı daha çok kullanıcıların kendi aralarında en çok takip edilen TikTok hesapları için kullandıkları bir niteleme olarak kabul görmektedir. Bu hesaplar, en temelde viral içerikler üreterek olabildiğince daha fazla kişi tarafindan izlenmek ve takip edilmeyi hedeflemektedir. Burada özellikle TikTok'un çalışma algoritması içerisinde trend olan içerikleri yakalayabilen ve bu noktada özgün içerikleri çarpıcı başlıklarla izleyicisine beğendirebilen hesaplar TikTok ünlüsü/fenomeni olmaktadır (Stay, 2021, s. 119-120). Tıpkı YouTube ve Instagram'daki fenomenler gibi TikTokerlar da TikTok'ta bulunan diğer kullanıcılardan bu yönleriyle kendilerini farklı kılarak birer sosyal medya etkileyicisine dönüşmektedir (Masanet vd., 2020).

TikTok'ta kendilerini fenomen kılmak isteyen kişiler, bu mecrayı daha çok kendileri için bir ispatlama aracı olarak kullanmaktadır. Nitekim ilk 10 Türk TikToker fenomenine bakıldığında, birkaç TikTok hesabı dışında TikTokerların diğer sosyal medya hesaplarındaki takipçi sayısı oldukça düşük sayıda kalmıştır. Aslında TikTokerların bu denli bilinir hâle gelmesinde, pandemiyle birlikte birçok kesimin iş hayatından uzaklaşması veya işlerini kaybetmesiyle TikTok'un bir gelir kapısı misyonuna dönüşmesi de etkili olmuştur. Örneğin; Kuzey İtalya'da TikTok yayını yapan ve dünyada en çok takip edilen hesaplardan biri olan Khabane Lame'nin (@Khabby.lame) TikTok macerası, pandemi döneminde işini kaybetmesiyle başlamıştır (Horowitz ve Lorenz, 2021).

TikTokerlar, diğer sosyal medya uygulamalarındaki etkileyiciler gibi ya TikTok hesabı olmadan önce ya da sıradan bir TikTok kullanıcısıyken zamanla bu platformda bulunan izleyicilerin dikkatini çekerek etkileşim ve takipçi sayılarıyla fenomen bir kişilik kazanmıştır. TikTok'ta fenomen olma durumu sadece hesap veya birey odaklı düşünülmemelidir. Bir iş yeri, mekân veya rumuz; söz ve hareket, makyaj, saç stili, giyim tarzı da hesap tarafindan popüler kılınabilmektedir. Antalya Aksu ilçesinde TikTok'a içerik üreten Mehmet Dinç'e ait cilgindondurmaci hesabı buna örnek olarak gösterilebilir. Dinç'in TikTok için ürettiği ana şey kendine has tarzıyla yaptı̆̆ı dans şovudur. Önceki yıllarda yine aynı mantıkla Instagram'da nusr_et hesabının yaptığı tuz serpme hareketi de tüm dünyada ünlenerek Nusret Gökçe'ye şöhret kapılarını aralatmıştır. Bu örnekler, sosyal medyada herkes tarafindan bilinen bir hesap olabilmenin yolunun özel bir taktik izlenmesiyle olabileceğini göstermektedir. 
TikTok hesapları; çocuklara özgü içerik üretenler (kidtoker), aileyi öne koyan içerikler paylaşanlar (familytoker), orta yaş ve üstünü hedefleyenler (elderly tiktoker), üretilen içeriği kurmacaya dayandıranlar (doublingtoker) ve içeriğin bizatihi kendisinin ön planda tutulduğu (dancetoker) paylaşımlar yapan hesaplar şeklinde de TikTokerlar sınıflandırılabilir. Bu sınıflandırma önerisini belirleyen ana unsur, hesabın daha çok hangi tema bağlamında kendini konumlandırdığıyla ilişkili olmuştur. Her bir ülkede TikTok içerik üreticileri farklı temalara yoğunlaşarak takipçi sayılarını artırmaktadır. Çalışmanın bundan sonraki kısmında Türk TikTokerlara yoğunlaşılmıştır.

Sosyal medyadaki yoğun takipçili hesaplar için mikro ünlüler şeklinde önceleri bir kavramlaştırma yapılırken (Senft, 2008, s. 25) sonraki yıllarda takipçi sayısından hareketle mikro (99.999 ve alt), makro (100.000 - 999.000) ve mega (1 milyon ve üzeri) sosyal medya etkileyicileri sınıflandırmasıyla bu kişiler için bir kategori geliştirilmiştir (Gómez, 2019, s. 17). Bu kategoride belirleyici role sahip olan değişken, takipçi sayısı olmuştur. Fakat takipçi sayısı dışında etkileyicinin yayın yaptı̆̆ dilin konuşulduğu ülke sayısı, bu ülkelerin nüfusu ile etkileyicinin vatandaşı olduğu ülkenin nüfusu da bu sınıflandırmada belirleyici olmalıdır. Resmî dili çok kısıtlı bir alanda konuşulan ve oldukça az nüfuslu bir ülke için (Estonya, Litvanya vb. ülkeler) burada belirlenen takipçi sayıları çok uçuk kalacaktır. Dil ve nüfusun yanı sıra etkileyicinin aldığı izlenme, beğeni, yorum sayıları gibi etkileşimler de bu sınıflandırmada olması gerekir. Nitekim sıradan bir sosyal medya kullanıcısı ile sosyal medya fenomeni arasındaki en keskin fark; hesabın aldığı etkileşim ve takipçi sayısıdır. Gómez (2019), sosyal medya fenomeni nitelendirmesini takipçi sayısıyla entegreli bir biçimde ifade etmektedir. Tablo 1'de Gómez'in takipçi sayısı ölçütü referans alınarak Türkiye'deki ilk 10 mega TikToker listesi hazırlanmıştır.

Tablo 1. Türkiye'de En Çok Takip Edilen TikTokerlar

\begin{tabular}{|c|c|c|c|c|c|c|c|}
\hline & Hesap Adı & $\begin{array}{c}\text { Takip } \\
\text { Ettiği }\end{array}$ & Takipçi & $\begin{array}{c}\text { Beğeni- } \\
\text { ler }\end{array}$ & $\begin{array}{c}\text { Hesap } \\
\text { Onayı }\end{array}$ & $\begin{array}{c}\text { Sayfadaki } \\
\text { Diğer Sosyal } \\
\text { Medya Hesap- } \\
\text { ları }\end{array}$ & $\begin{array}{c}\text { Kate- } \\
\text { gori }\end{array}$ \\
\hline 1 & cznburak (E) & 0 & $50.6 \mathrm{M}$ & $944.8 \mathrm{M}$ & Var & YouTube & Gıda \\
\hline 2 & nnursema (K) & 134 & $17.4 \mathrm{M}$ & $392 \mathrm{M}$ & Var & Yok & Sanat \\
\hline 3 & $\begin{array}{c}\text { cilgindondur- } \\
\text { maci_(E) }\end{array}$ & 111 & $15.1 \mathrm{M}$ & $146.2 \mathrm{M}$ & Yok & YouTube & Gıda \\
\hline 4 & $\begin{array}{c}\text { yesimresmi1 } \\
\text { (K) }\end{array}$ & 67 & $12.2 \mathrm{M}$ & $224.1 \mathrm{M}$ & Yok & YouTube & Eğlence \\
\hline
\end{tabular}




\begin{tabular}{|c|c|c|c|c|c|c|c|}
\hline 5 & nusr_et (E) & 0 & $11 \mathrm{M}$ & $88 \mathrm{M}$ & Var & Yok & Gıda \\
\hline 6 & aydas (K) & 316 & $10.6 \mathrm{M}$ & $170 \mathrm{M}$ & Var & YouTube & Eğlence \\
\hline 7 & $\begin{array}{c}\text { korayzeynep } \\
\text { (H) }\end{array}$ & 0 & $9.8 \mathrm{M}$ & $226.6 \mathrm{M}$ & Var & YouTube & Çocuk \\
\hline 8 & $\begin{array}{c}\text { cemresolmaz } \\
(\mathrm{K})\end{array}$ & 110 & $8.9 \mathrm{M}$ & $707.8 \mathrm{M}$ & Var & YouTube & Eğlence \\
\hline 9 & cerenyaldz (K) & 102 & $8.7 \mathrm{M}$ & $672.7 \mathrm{M}$ & Var & YouTube & Eğlence \\
\hline 10 & cellat36 (E) & 54 & $8 \mathrm{M}$ & $371 \mathrm{M}$ & Var & Yok & Eğlence \\
\hline
\end{tabular}

Türkiye'de en çok takip edilen ilk 10 TikTok hesabında kadın ve erkek kullanıcılar neredeyse aynı oranda listeye girmiştir. Türk TikTokerlar içerisinde en çok takip edilen ve etkileşim alan hesap cznburak isimli TikTok hesabı olmuştur. Burak Özdemir'e ait cznburak isimli hesabın aynı zamanda YouTube ve Instagram'da da ciddi oranda takipçi sayısı bulunmaktadır. Diğer sosyal medya platformlarında da önemli oranda takipçisi bulunan bir diğer hesap Nusret Gökçe'ye ait nusr_et isimli TikTok hesabı olmuştur. Bu iki TikTok hesabı dışında kalan sekiz TikToker, TikTok uygulamasıyla birlikte ünlenmiştir.

TikTok'ta onaylı hesaba mavi tik onayı TikTok tarafindan verilmektedir. İlk 10 Türk TikToker hesabı içinde sadece iki hesabın (yesimresmi1, cilgindondurmaci_) mavi tik onayı bulunmamaktadır. Listedeki Türk TikTokerların üçü hariç, tüm diğer TikTokerlar ayrıca YouTube hesaplarına da erişim linki bırakmıştır. TikTokerlar TikTok'ta takipçi ve izlenme sayısıyla paralel olarak artan kazanç rakamlarını YouTube üzerinden de artırmayı hedeflemiştir. Türk TikTokerlar, eğlence içerikli yayınları daha fazla izleyicilerine sunmuştur. Türk TikTokerlardan cznburak, nusr_ et ve korayzeynep hesaplarının TikTok'taki herhangi bir hesabı takip etmediği, bu iki hesap dışında kalan diğer TikTokerlarınsa ya takipçilerini ya da platformdaki diğer TikTokerları takip ettiği tespit edilmiştir. Öte yandan aydas isimli hesap, ilk 10 TikTokera göre daha fazla TikTok hesabı takip etmiştir. 


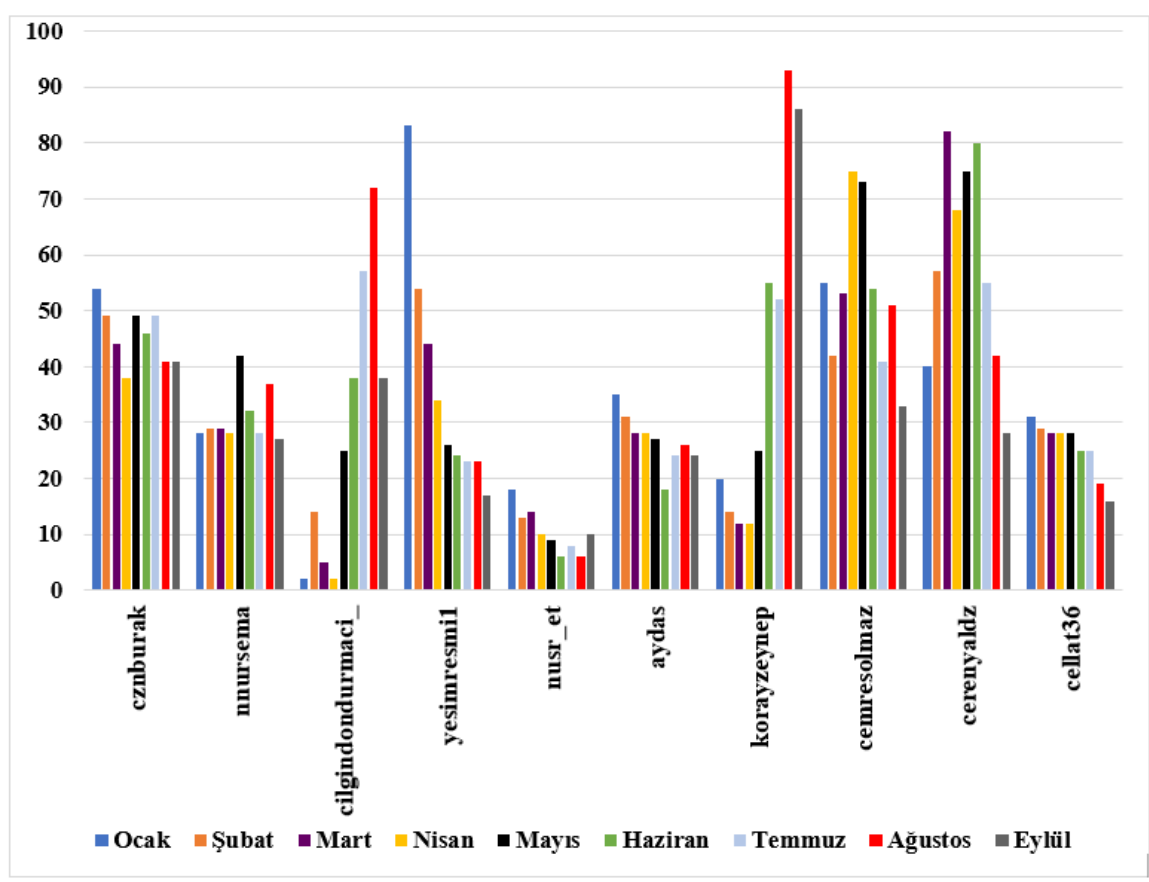

Şekil 1. Aylık Bazda TikTokerların İçerik Paylaşım Sayıları

Türk TikTokerların 2021 yılının ilk dokuz ayı (1 Ocak - 30 Eylül) içerisinde yaptı̆̆ paylaşım sayılarını ortaya koyan üstteki şekle göre bu dokuz ay içerisinde en çok paylaşım yapan hesapların ortalaması sırasıyla; cerenyaldz $(62,375)$, cemresolmaz $(55,75)$, cznburak $(46,25)$, yesimresmi1 $(38,875)$, korayzeynep $(35,375)$, nnursema $(31,625)$, aydas $(21,125)$, cilgindondurmaci_ $(26,875)$, cellat36 $(26,625)$ ve nusr_et $(10,5)$ şeklinde olmuştur. Bu sıralama aynı zamanda günlük bazda en çok paylaşım yapan hesapların sıralamasını da vermektedir. Türk TikTokerların aylık içerik paylaşma ortalaması alındığında, ağustos (41) ayı en çok paylaşım yapılan ay olmuştur. Ağustos ayının ortalamasını sırasıyla; mayıs $(37,9)$, haziran $(37,8)$, ocak $(36,6)$, temmuz $(36,2)$, mart $(33,9)$, şubat $(33,2)$, nisan $(32,3)$ ve eylül $(32)$ ayları takip etmiştir.

\section{Amaç ve Yöntem}

Akademi alan yazında son üç yıldır TikTok hakkında yapılan uluslararası çalışmalarda daha çok bilgisayar bilimleriyle ilgili yazılar başı çekmiştir (Zeng vd., 2021, s. 3166). Ülkemizde iletişim bilimleri alanında TikTok hakkında yapılan çalışmalarda; tüketici davranışları, influencer pazarlama, toplumsal norm ve değerlerin tahrifi, 
TikTok hakkında getirilen eleştiriler ve izlenim yönetimi konularına odaklanılmıştrr (Yıldız, 2019; Uğurhan ve Yaşar, 2021; Akpınar, 2021; Şeker, 2021; Gedikoğlu ve Atalay, 2021). Fakat burada ana role sahip dijital içerik üreticilerinin (TikTokerlar) paylaşımlarına ilişkin ülkemizde herhangi bir çalışma yapılmamıştır. Çalışma, literatürdeki bu boşluğu giderecek niteliğe haizdir. Söz konusu araştirmada; Türkiye'de TikTok uygulaması üzerinden içerik paylaşan Türk TikTokerların paylaşımlarını konu edinmektedir. Bu noktadan hareketle araştırma; Türkiye'de milyonlarca kişi tarafindan takip edilen Türk TikTokerların paylaşımlarını inceleyen ilk çalışma niteliğine sahiptir. Türk TikTokerların içerik paylaşım pratiklerini ortaya çıkartmayı amaçlayan bu çalışmada; en çok takip edilen Türk TikToker hesaplarının hangileri olduğu, bunların ne paylaşthğı, paylaşımlarında hangi değişkenlerin öne çıktığı, TikTokerlar arasında benzeşen ve ayrışan yönlerin olup olmadığı soruları ile takip edicilerin söz konusu paylaşımları izleme, beğenme ve yorum yapma sayılarına cevap aranmaya çalışılmıştır. Araştırmada spesifik özellikleri taşıyan ve bu noktada aynı sosyal medya uygulamasında paylaşım yapan TikTok hesapları, amaçlı örneklemin homojen örneklem tekniğinden yararlanılarak belirlenmiştir (Etikan vd., 2016, s. 3). Araştırmanın veri setini; en çok takip edilen 10 TikTok hesabının (Tablo 1) 2021 yılının ilk dokuz ayı içerisinde en fazla paylaşımda bulundukları (Şekil 1) ağustos ayındaki paylaşımları oluşturmuştur.

Berelson (1952, s. 18) bir iletinin içeriği; sistematik, nesnel ve sayısal anlamda incelemeye olanak vermesi hâlinde, bunun nicel içerik analizi tekniği kullanılarak incelenebileceğini belirtmiştir. Nicel içerik analizi; sosyal bilimler alanında iletiler üzerinde tanımlayıcı veriler elde etmede sıklıkla kullanılan istatiksel bir araştırma tekniğidir (George, 2003, s. 11). Kayıtlı tüm iletişim biçimlerinin sembolik içeriğini sistematik olarak değerlendiren bu analiz; sözcük, resim video vb. tüm medya içeriklerinin analizi için oldukça kullanışlıdır (Kolbe ve Burnett, 1991, s. 243). Bu analizin temel amacı; araştırma veri deseninde kategori sıklığını belirlemek, bu kategorileri sayısal hâle getirip çetelesini tutmak ve en nihayetinde üzerinde analizler yaparak raporlaştırmaktır (Hansen, 2000, s. 55). Yapılan araştırmanın veri setinin yukarıda sıralanan özelliklere sahip olması nedeniyle çalışmada nicel içerik analizi yöntemi kullanılmıştır. Araştırmada; verilerin toplama sürecinden raporlaştırma aşamasına kadarki tüm süreçler, nicel içerik analizi literatürünce ortaya konulan adımlar doğrultusunda ilerlenerek hareket edilmiştir (White ve Marsh, 2006, s. 30; Riffe vd., 2019, s. 149).

Araştırmada incelenen TikTok videolarını sınıflandırmada; TikTok ve sosyal medya fenomenleri özelinde yapılan çalışmalar ile kodlama sürecinde ortaya çıkan 
yeni değişkenler altında video içerikleri kategorileştirilmiştir. Literatürden alınan kategoriler; dans, komedi/mizah, pleybek, bireysel yetenekler (Weimann ve Masri, 2020, s. 3) müzik, profesyonel sahneler, düello/meydan okuma (Miller, 2020, s. 212-213), doküman/yazı, gelen tepkiler veya abonelikler hakkındaki açıklamalar, birden çok TikTok özelliğinin (filtreler ve görsel efektler) aynı anda kullanılması (Schellewald, 2021, s. 1443-1450) deney, şaka, makyaj, yemek, seyahat, bilgi, soru cevap (Sezer ve Özcan, 2021, s. 130), eğlence ve taklit (Tam, 2020, s. 1343) kategorileri olmuştur.

Araştırmada incelenen tüm Türk TikTokerların hesapları, araştırmacı tarafindan açılan bir TikTok hesabıyla takip edilmiştir. Türk TikTokerların hesaplarına ait profil bilgisi ve paylaşımlarına ait istatistiklerin çetelesi (takipçi, takip edilen ve beğeni sayıları) ile paylaşılan içeriklerin künye (içeriğin paylaşıldığı tarih, süre, etkileşim sayıları) ve teknik (ses ve görüntü) bilgileri her ay düzenli olarak excel dosyasına aktarılmıştır. Araştırmaya ait veriler kodlanmadan önce yukarıda belirtilen kategoriler özelinde kod cetveli oluşturulmuştur. Kod cetvelinde bulunmayan içerikler yeni bir değişkenle adlandırılarak kod cetveline tanımlanmıştır. Daha sonra ise her bir video içeriği excelde açılan çalışma sayfası üzerinden kodlanmıştır. Araştrrmaya ait tüm verilerin kodlama süreci bitirildikten sonra kodlanan veriler belirli temalar altında birleştirilmiştir (Schreier, 2012). Tüm bu süreçlerden sonra güvenirlilik ve geçerlilik adımlarına geçilmiştir.

İçerik analizinde güvenirlilik ile ilgili tartışmalar hâlen devam etmekte ve hâli hazırda bu noktada bir uzlaşı bulunmamaktadır. Güvenirliliğe ulaşmadaki yol ve yöntemlerden, hesaplamanın gerçekleştirileceği indislerin hangileri olacağına kadar birçok teknik ve görüş alan yazında bulunmaktadır (Lombard vd., 2004, s. 435). Araştırma güvenirliği; kodlayıcılar arası uyum derecesi ile kategorilerin tanım, tür ve ayrımının net bir biçimde belirlenebilmesine bağlıdır (Holsti, 1969). Krippendorff (2004, s. 413) güvenirlik için birbirinden bağımsız iki farklı kodlayıcının verileri kodlamasını ve bu iki kodlayıcının kodlamış olduğu veri setinin karşılaştırmasını önermektedir. Söz konusu öneri ışığında, araştırmacıdan bağımsız gerçekleştirilen bir başka kodlayıcıyla araştırmanın literatürdeki güvenilir (Cohen's k = \%92,7) seviyesini yakaladığı görülmüştür (Neuendorf, 2012, s. 234; Kassarjian, 1977, s. 14).

Nicel içerik analizinde, belirlenen kategoriler üzerinden araştırmanın iç geçerliliğini sağlamak için kategorik hâle getirilen değişkenler, içerik analizini bilen bir başka kişi tarafindan da aynı şekilde sınıflandırılmalıdır (Donald, 1956, s. 103). Bu yöntemin bir diğer adı uzman incelemesi şeklinde ifade edilmektedir (Creswell, 1998, s. 202). Yapılan araştırmada üstte belirtilen kategorilerin iç geçerliliğini 
sağlamak adına Delfi metodundan (Dalkey ve Helmer, 1963; Jordan ve Javernick-WiLL, 2013, s. 23) hareket edilerek söz konusu değişkenler iletişim alanından uzmanların incelemesine sunulmuştur. Yapılan değerlendirmelerde katılımcıların her biri, kodlanmış veriye ilişkin hazırlanan kategori ve açıklamalardan hareket ederek her bir kategori için 1 ila 5 üzerinden bir puanlamada bulunmuştur. Yapılan ilk uzman değerlendirmesi sonucunda genel ortalama 3.98 iken düzeltme önerileriyle ikinci geri bildirimin ortalaması 4.62'ye çıkmıştır (Şekil 2). Çalışmanın dış geçerliliği içinse, seçilen örneklem grubunun araştırmadaki temsil edilebilirliğini arttırma (Neuendorf, 2012, s. 115) ve aynı evreni çalışan araştırmacıların aynı yöntemle benzer örnekleme seçimine gideceği varsayımından (Krippendorff, 1980, s. 87) hareket edilmiştir.

Şekil 2. Kategoriler Hakkında Uzman Görüşü

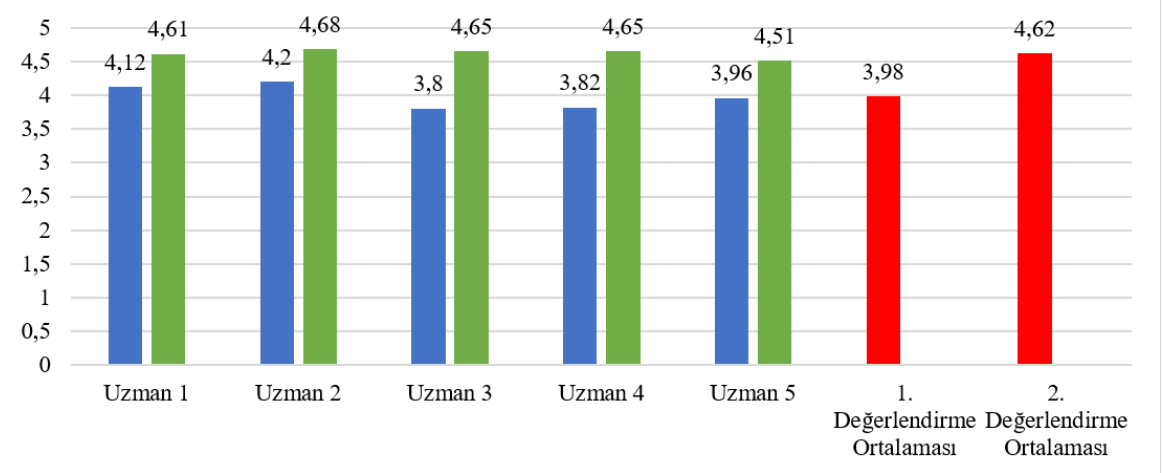

1. Değerlendirme $\because 2$. Değerlendirme

Türk TikTokerların paylaşımlarını konu edinen bu araştırmada, bazı sınırlılıklar belirlenerek hareket edilmiştir. Bunlar:

1. Türkiye'de en çok takip edilen ilk 10 TikTok hesabı incelemeye alınmıştır.

2. TikTokerların canlı yayın içerikleri araştırmaya dâhil edilmemiştir.

3. Analiz edilen TikTok içerikleri 01.08.2021-31.08.2021 tarihi ile sınırlı tutulmuştur.

4. Kullanıcıların videolara yaptığı yorumlara sadece sayısal anlamda bakılmıştır.

5. Videolar gösterge bilimsel anlamda değerlendirilmemiştir.

6. Takipçi ve videoların etkileşim sayılarına 30.09.2021 tarihine kadar bakılmıştır. 


\section{Bulgular}

Türk TikTokerların yaptığı paylaşımlara ilişkin araştırma soruları hazırlanarak söz konusu içerik üreticilerinin paylaşım pratikleri keşfedilmeye çalışılmıştır. Araştırma verileri doğrultusunda hazırlanan ilk soru; Türk TikTokerların ortalama kaç saniyelik videolar paylaşth̆ ve bu içeriklere kullanıcıların ortalama ne kadar etkileşimde (beğeni, yorum, izlenme) bulunduğudur. Türk TikTokerların ağustos ayı içerisinde yapmış olduğu paylaşımların ortalama video süresi 24,9 saniye (sn) tutmuştur. Bu sürelerin bir dakikadan daha az olduğu görülmüştür. TikTok kullanıcıları nezdinde değerlendirildiğinde; yesimresmi1 hesabı en düşük süre ortalamasına (11.217 sn) sahip kullanıcı olurken, cilgindondurmacı_ hesabı ise en uzun süre ortalamasına $(49,431 \mathrm{sn})$ sahip içerik üreticisi olmuştur. Ağustos ayı etkileşim düzeylerine bakıldığında; her ne kadar en çok takipçiye sahip TikTok hesabı cznburak isimli kullanıcı olsa da (48.3 M), en fazla etkileşim alan TikTokerın takipçi sayısında dördüncü sırada bulunan yesimresmi1 hesabı (izlenme ve beğeni) ve onuncu sıradaki cellat36 (yorum) hesapları olduğu göze çarpmaktadır (Tablo 2). TikTok'ta hesap oluşturulma tarihinden itibaren etkileşim sayıları değerlendirildiğinde ise en fazla beğeni alan hesap cznburak adlı Burak Özdemir'e ait TikTok kullanıcısı olmuştur. Söz konusu hesabı sırasıyla; cemresolmaz, cerenyaldz, nnursema, cellat36, korayzeynep, yesimresmi1, aydas, cilgindondurmaci_ve nusr_et hesapları izlemiştir (Tablo 1).

TikTok içerik üreticileri, yoğun olarak paylaşımlarında etiketleme (hashtag) yoluna gitmiştir. Aydas Sadık (aydas) isimli kullanıcı, TikTok içeriklerinde etiketlemeyi çok sık bir biçimde kullanan TikToker olmuştur. İlgili hesap daha çok Arapça etiketler oluşturarak Orta Doğu'daki TikTok kullanıcılarını hedeflemiştir, aydas'ın TikTok'ta bu tarz bir stratejiye başvurmasında aynı zamanda kendisinin Irak ve İran kökenli bir aileden gelmesi ve Arapçayı iyi derecede bilmesi de etkili olduğu düşünülmektedir. Ağustos ayındaki TikTok içeriklerinde herhangi bir etiket kullanmayıp paylaşımda bulunan hesaplar da olmuştur. yesimresmi1, korayzeynep ve cerenyaldz hesapları ağustos ayındaki içeriklerinde herhangi bir etiket kullanmadan içerik paylaşan TikTokerlardır.

Genel bir bakış açısıyla Türk TikTokerların içerikleri değerlendirildiğinde, Türkiye'deki TikTok içerik üreticileri bir dakikanın altındaki içerikleri daha sık paylaştı̆̆, bu paylaşımların her birinin ortalama 372 bin beğeni, 6000 yorum aldığı ve Türk TikTokerların TikTok'ta yaptığı her bir paylaşımın ortalama beş milyon izlendiği Tablo 2'de ortaya çıkmaktadır. Erkek TikTokerların içerikleri kadın TikTokerların paylaşımlarına göre daha fazla beğenilmiş ve izlenilmiştir. Diğer yandan, kadın TikTokerların paylaşımlarına erkek TikTokerlarınkine kıyasla daha fazla yorum yapılmıştır. 
Tablo 2. Paylaşılan TikTok İçeriklerinin Süresi ve Etkileşim Performansı

\begin{tabular}{|c|c|c|c|c|c|c|}
\hline & Hesap Adı & $\begin{array}{l}\text { Orta- } \\
\text { lama } \\
\text { Video } \\
\text { Süresi }\end{array}$ & $\begin{array}{c}\text { Ortalama } \\
\text { Beğeni Sayısı }\end{array}$ & $\begin{array}{c}\text { Ortalama } \\
\text { Yorum } \\
\text { Sayısı }\end{array}$ & $\begin{array}{c}\text { Ortalama } \\
\text { İzlenme Sayısı }\end{array}$ & $\begin{array}{l}\text { Videolar- } \\
\text { da Etiket } \\
\text { Kullanımı }\end{array}$ \\
\hline 1 & cznburak & $\begin{array}{l}27.96 \\
\text { saniye }\end{array}$ & 1.340 .900 & 7947,8 & $9.678 .048,78$ & Evet \\
\hline 2 & nnursema & $\begin{array}{l}23,081 \\
\text { saniye }\end{array}$ & $115.667,55$ & 5814,09 & 4.579.870,19 & Evet \\
\hline 3 & $\begin{array}{l}\text { cilgindon- } \\
\text { durmaci_ }\end{array}$ & $\begin{array}{l}49,431 \\
\text { saniye }\end{array}$ & $250.594,44$ & 3668,67 & $6.463 .888,89$ & Evet \\
\hline 4 & yesimresmi1 & $\begin{array}{l}11.217 \\
\text { saniye }\end{array}$ & $813.991,30$ & $12.714,91$ & $13.060 .869,57$ & Hayır \\
\hline 5 & nusr_et & $\begin{array}{l}32,833 \\
\text { saniye }\end{array}$ & 478.200 & 2749 & $4.658 .066,67$ & Evet \\
\hline 6 & aydas & $\begin{array}{l}13,154 \\
\text { saniye }\end{array}$ & $233.919,23$ & 3055,62 & $3.738 .461,54$ & Evet \\
\hline 7 & korayzeynep & $\begin{array}{l}24,903 \\
\text { saniye }\end{array}$ & $24.751,75$ & 128,34 & $2.037 .148,39$ & Hayır \\
\hline 8 & $\begin{array}{c}\text { cemresol- } \\
\text { maz }\end{array}$ & $\begin{array}{l}13,51 \\
\text { saniye }\end{array}$ & $404.333,33$ & 1135,51 & $5.231 .372,55$ & Evet \\
\hline 9 & cerenyaldz & $\begin{array}{l}13,381 \\
\text { saniye }\end{array}$ & $268.711,90$ & $11.818,12$ & $3.158 .333,33$ & Hayır \\
\hline 10 & cellat36 & $\begin{array}{l}14,842 \\
\text { saniye }\end{array}$ & $706.457,89$ & 17.142 & $8.410 .526,32$ & Evet \\
\hline \multicolumn{3}{|c|}{ Genel Toplam } & 152.603 .813 & 2.471 .261 & 2.116 .422 .100 & \\
\hline \multicolumn{2}{|c|}{ Genel Ortalama } & $\begin{array}{c}24,9 \\
\text { saniye }\end{array}$ & $372.204,42$ & 6027,47 & 5.162 .005 & \\
\hline
\end{tabular}

TikTokerların TikTok hesaplarında ne paylaştğı ve TikTok fenomenlerinin paylaşımlarında hangi teknik (görüntü ve seslendirme) pratikler kullandığına ilişkin iki araştırma sorusu oluşturulmuştur. Türk TikTokerlar, sosyal medya diliyle ifade edilen akımları diğer tüm başlıklara göre daha fazla paylaşmıştır $(\% 46,10)$. Orijini itibariyle bir müzik uygulamasından gelen TikTok'ta Türkiye'deki dijital içerik üreticileri dans $(\% 30,98)$ ve eğlence $(\% 27,56)$ içerikli paylaşımları da yoğun bir biçimde TikTok'a yüklemiştir. Söz konusu bu içeriklerin \%49,51'i kesik kesik görüntüler yerine sadece tek bir düz çekimle kameraya alınarak TikTok'ta paylaşılmıştır. Bu çekimlerde, herhangi bir konuşmaya yer vermeden arka plana konulan popüler bir müzik içerikleriyle söz konusu paylaşımların montajlanarak izleyiciye sunulduğu tespit edilmiştir (Tablo 3). 
Tablo 3. TikTok'ta Öne Çıkan Niteliksel Özellikler ile Görüntü ve Seslendirme Pratikleri

\begin{tabular}{|c|c|c|c|}
\hline \multirow{2}{*}{\multicolumn{2}{|c|}{$\begin{array}{c}\text { Araştırma Sorusu } 2 \\
\text { Paylaşımın Niteliksel Özellikleri }\end{array}$}} & \multicolumn{2}{|c|}{ Araştırma Sorusu 3} \\
\hline & & Görüntü & Seslendirme \\
\hline Deney \%0,24 & Eğlence \%27,56 & Emoji \%1,22 & Pleybek \%20,49 \\
\hline Bilgi \%1,22 & Taklit \%7,56 & Filtre $\% 5,61$ & Dublaj $\% 5,12$ \\
\hline $\begin{array}{l}\text { Yemek Yapma } \\
\% 3,41\end{array}$ & Akımlar \%46,10 & Montaj \%40,49 & Orijinal Ses \%11,46 \\
\hline Seyaha t\%0,49 & Gündem \%2,2 & Hızlandırılmış \%6,83 & Fon Müzik \%18,29 \\
\hline $\begin{array}{l}\text { Komedi/Mizah } \\
\% 2,93\end{array}$ & Moda \%1,71 & $\begin{array}{l}\text { Profesyonel Sahneler } \\
\% 0,98\end{array}$ & Orijinal Müzik \%43,66 \\
\hline $\begin{array}{l}\text { Aldatma/Kandır- } \\
\text { ma } \% 6,8\end{array}$ & Nasıl Yapılır \%3,41 & Düz Çekim \%49,51 & \\
\hline Makyaj\%2,20 & $\begin{array}{l}\text { Dişilik/Erkeksilik } \\
\% 10,49\end{array}$ & Doküman/Yazı \%3,17 & \\
\hline $\begin{array}{l}\text { Düello/Meydan } \\
\text { Okuma \%2,44 }\end{array}$ & $\begin{array}{l}\text { Bireysel Yetenekler } \\
\% 8,29\end{array}$ & \multirow{2}{*}{$\begin{array}{l}\text { Birden Çok Özelliği } \\
\text { Kullanma \%2,44 }\end{array}$} & \\
\hline Çizim \%4,63 & Dans \%30,98 & & \\
\hline
\end{tabular}

Araştırma sorusu 4'te; TikTok'ta TikTokerların paylaştığı videoları nerede (mekân) çektiği, hangi dille seslendirdiği ve bu içeriklerde kim/kimlerin bulunduğu sorulmuştur. Yapılan analiz sonucunda; içerik üreticilerinin paylaştı̆̆ her iki videodan birinin evde çekildiği $(\% 50,24)$ belirlenmiştir. Bunu iş yeri, kafe ve AVM gibi mekânlar izlemiştir (\%26,34). TikTokerların daha çok evde diğer bir ifadeyle kapalı mekânlarda içerik üretmesinde pandeminin getirdiği kısıtlamaların etkili olduğu düşünülmektedir. TikTokerların hesaplarına yükledikleri içeriklerde sadece kendisinin videoda olduğu içerikleri (\%40) daha sık bir biçimde hesaplarında paylaşmıştır. Diğer bir ifadeyle TikTokerların paylaşımlarındaki ana karakter kendileri olmuştur. Yapılan paylaşımlarda sıklıkla Türkçe $(\% 39,76)$ ve İngilizce $(\% 35,12)$ kullanılarak takip edicilere hitap edilmiştir. Bu seslendirme sadece konuşarak değil aynı zamanda şarkılara yapılan pleybeklerle de sürdürülmüştür.

Tablo 4. Videolardaki Mekân, Kişi ve Dil Özellikleri

\begin{tabular}{|l|l|l|}
\hline \multicolumn{3}{|c|}{ Araştırma Sorusu 4 } \\
\hline Mekân & Videodaki Kişiler & Dil \\
\hline Ev \%50,24 & Tek \%40 & Türkçe \%39,76 \\
\hline Sokak \%8,54 & Arkadaş \%5,37 & İngilizce \%35,12 \\
\hline Araba \%1,46 & Sosyal Çevre \%20,73 & Arapça \%21,22 \\
\hline
\end{tabular}




\begin{tabular}{|l|l|l|}
\hline İş yeri /AVM \%26,34 & Çocuk \%16,83 & İspanyolca \%2,68 \\
\hline Sahil \%3,66 & Çekirdek Aile \%5,85 & Rusça \%0,98 \\
\hline Çöl \%0,73 & Diğer TikTokerlar \%2,93 & Kürtçe \%0,73 \\
\hline Orman \%0,98 & Ünlüler \%1,46 & \\
\hline
\end{tabular}

TikTokerların diğer TikTokerlar veya ünlüler ile hazırladığı içerikler öteki içeriklerine göre daha fazla izlenme ve etkileşim almıştır. TikTokerların özellikle hesaplarına ait takipçi ve etkileşim sayılarını yükseltmek adına bu tür iş birliklerine giriştiği söylenebilir. TikTokerlar, TikTok'ta bilinir olduktan sonra gerçekleştirmeye çalıştıkları bir diğer başarı; geleneksel medya araçlarında görünür veya bilinir olmaktır. Bunu gerçekleştirmeye çalışan hesaplar oyuncu veya şarkıcı ya da her ikisi özelinde yapmaya çalışmıştır. Nitekim Türk TikTokerlar hazırladıkları TikTok yayınları dışında kendilerine ait müzik klipleri çekerek bu noktada da kendilerini farklı sosyal medya mecralarında pazarladığı gözlemlenmiştir. Bu yaklaşımı cilgindondurmaci_, aydas, cemresolmaz ve cerenyaldz hesapları benimsemiştir. Söz konusu dört hesap hem TikTok hem de YouTube hesapları üzerinden, şarkılarını takip edicilerine duyurma gayreti göstermiştir. Bu noktada netd müzikle iş birliği yapan hesaplar da (aydas) olmuştur.

\section{Tartışma ve Sonuç}

Tıpkı YouTube'da olduğu gibi TikTok da kullanıcılarına kendileriyle ilgili bir video ansiklopedisi oluşturma gayesine hizmet etmektedir. TikTok kullanıcıları; günlük rutinler, anlık tepkiler, özel anlar, beğendikleri veya ilgilendikleri kategorilerdeki videoları TikTok'a yükleyerek kendi özel hayat ve ilgi alanıyla alakalı dijital bir video arşivi oluşturmaktadır (Zhang, 2020, s. 226). TikTokerları sıradan kullanıcılardan ayıran en önemli fark; dijital kültür bağlamında çeşitli içerikleri kendilerine has bir tarz ile sunarak bir tema çerçevesinde konumlandırmasıdır. Öte yandan takipçi ve etkileşim sayılarının diğer kullanıcılara nazaran yüksek sayılarda olması da TikTokerları diğer içerik üreticilerinden farklı kılmaktadır.

Türkiye'de en çok takip edilen 10 TikToker hesabının örneklem alındığı bu araştırmada; Türk TikTokerların paylaşım pratikleri nicel anlamda keşfedilmeye çaIışılmıştır. Araştırmada, en çok takip edilen Türk TikTokerların abone sayılarının kendi içinde farklılıklar barındırdığı tespit edilmiştir. Türkiye'deki TikTok üzerinden içerik üreten ilk 10 Türk TikTokerın takipçi sayısı sekiz milyon ve üzerini geçmektedir. TikTok hesaplarındaki takipçi sayısı izleyicilerden gelebilecek etkileşimi belirleyebilmekte fakat Türk TikTokerlarda bu durum en fazla takip edilen hesaplarla paralel bir şekilde gerçekleşmemiştir. Daha çok Z Kuşağının deneyimlediği 
TikTok'ta (Bangs, 2020, s. 7) izleyiciler, kendi ilgilerini çeken ve nispeten daha genç olan kişilerin video içeriklerine daha fazla etkileşimde bulunmuştur. Nitekim hem beğeni hem de izleme sayılarında en fazla etkileşim alan hesapların yaşı diğer TikTokerlara göre daha düşük kalmıştır. Bu durum, Türkiye'de TikTok’a katılım sağlayan kesimin daha çok Z kuşağı çağındaki bireyler olduğuna dair bir varsayımı doğurmaktadır. Burada etkileşimi belirleyen bir diğer değişkense video sürelerinin kısa tutulma stratejisi olmuştur. Paylaştı̆̆ içeriğin süresini kısa tutan TikTokerların izlenme ve beğeni performansı, daha uzun içerikler üreten TikTokerlara göre daha yüksek oranda gerçekleşmiştir. TikTokerların yorum alma performansında ise sansasyonel ve absürt içerikler daha fazla belirleyici olmuştur. Öte yandan, araştırmada TikTokerların diğer TikToker veya ünlülerle birlikte hazırladığı içeriklere de rastlanmıştir. Bu iş birliğini içeren içeriklerin izlenme, beğeni ve yorum sayıları diğer içeriklere göre daha yüksek olmuştur.

Etkileşim sayılarından ziyade genel anlamda fenomen hesaplar için takipçi sayısı, interaktiflik ve iş potansiyelinden yola çıkılarak nitelendirme yapılmaktadır (Gómez, 2019; Li, 2018). Bu sıralananlara ek olarak TikTok içeriklerinin izlenme, yorum ve beğeni sayıları da fenomen kişilikler için belirleyici bir kriter olmalıdır. Çünkü TikTok gibi popüler sosyal medya uygulamalarında kullanıcılar kendi hakkında olumlu bir imaj gösterebilmek adına bot denilen sahte takipçilerle hesaplarının takipçi sayılarını artırabilmektedir (Kolomeets ve Chechulin, 2021). Bu durum, TikTokerın oldukça geniş bir takipçi kitlesi bulunduğuna dair hatalı bir istatistik vererek takip ediciler nezdinde ilgili TikTokerın bir fenomen olduğuna ilişkin yanlış bir kanaat da oluşturmaktadır.

Sosyal medya akımları; yurt içi veya dışında gerçekleşen bir hareket, eylem, dans, müzik, duruş, söz veya film içeriğinin TikTok veya diğer sosyal medya uygulamalarına uyarlanarak paylaşılması şeklinde ifade edilebilir. Böylece bu kopyalama, uyarlama veya seri üretim sosyal medya diliyle bir akıma dönüşmektedir. Araşttrmada, bir içerik izleyiciler tarafindan yoğun etkileşim almışsa hemen hemen tüm TikTokerların popüler olan bu içeriği kendine uyarlayarak takipçilerin beğenisine sunduğu görülmüştür. Türk TikTokerların özgün içeriklerden ziyade, özellikle yurt dışında popüler olan içerikleri kendilerine göre kurgulayıp izleyicisinin karşısına çıkmıştır. Sadece içerikle değil aynı zamanda diğer ülkelerde olduğu gibi (Subramanian, 2021), popüler olan şarkılar veya pleybek yöntemiyle de TikTokerlar içerik paylaşımında bulunmuştur. TikTok'ta diğer sosyal medya platformlarında da sıklıkla karşılaşılan meydan okumalara da (challange) rastlanılmıştır. TikTok'ta yapılan canlı yayınlarda, içerik üreticileri söz konusu meydan okumalar için bir süre belirlemekte ve bu süre zarfinda izleyicilerden etkileşim almayı hedefle- 
mektedir. Sıklıkla canlı yayın akışlarıyla gerçekleştirilen bu kışkırtmalarda içerik üreticileri; farklı ideolojilere sahip kesimler veya bir performans üzerinden izleyicilerin kendilerini desteklemesini veya hak bildiği davasına takipçilerin de sahip çıkmasını sağlamaya çalışmaktadır. Daha sonra farklı hesaplarla TikTok tabiriyle "kapışarak" bunu bir akıma dönüştürmektedir. TikTok içerik üreticilerinin birbirlerinden aşırttiğı veya yurt dışından devşirdiği bu akımlar, platformun kendi işleyiş mantı̆̆ından da kaynaklanmaktadır. Platformun çıkış noktasını oluşturan Musical. ly uygulamasında kullanıcılar, paylaşılan içerikleri pleybek yoluyla bir nevi taklit ederek deneyimlemektedir. Akım videolarının TikTok'un kendi içinde barındırdığı paylaşım ve etkileşim kültürü ile çalışma mantalitesi bağlamında değerlendirilmesi daha doğru olacaktır.

TikTok içerik üreticilerinin ürettiği ana şey dijital dans kültürüdür (Boffone, 2021). Bu paylaşımlarda seksüalizm çok fazla öne sürülerek bunun üzerinden bir benlik sunumu gerçekleştirilmektedir (Khattab, 2020; Vizcaíno-Verdú ve Tirocchi, 2021; Kennedy, 2020). Yapılan araştırmada kadın TikTokerların bu tarz içerikleri daha sık paylaştı̆̆ bulgulanmıştır. Erkek TikTokerlar daha sık bir biçimde arkadaş çevreleriyle sosyal hayata dair (yemek yapma, arabaya binme vb.) ritüelleri paylaşmayı tercih ederken, kadın TikTokerlarsa sıklıkla tek başına oldukları ve yoğun olarak dış görünüşlerine ait (makyaj, kıyafet değiştirme vb.) içerikleri takipçileriyle paylaşmıştır. Öte yandan, Türk TikTokerlar genel anlamda video üzerinden kullanıcılarıyla iletişime geçmeyip video içeriklerine sabit tuttuğu yorumlarla takipçileriyle iletişim kurmaya çalışmıştır. Bu iletişim biçiminde, TikTokerlar kullanıcıların daha çok yorum yapmalarını sağlayacak şekilde (soru sorarak) kurgulamıştır. Soru sorma dışında, TikTokerlar periyodik aralıklarla açtı̆ı canlı yayınlarla takipçileriyle daha uzun süreli samimi bir iletişim sürecini de deneyimlemiştir. Ayrıca Türk TikTokerlar kendi sayfalarında; ürün yerleştirme, ticari mekân ve kendi marka kimliklerinin örtük veya açık bir şekilde reklamlarını yapmış ve bunu da içerik görüntüsü altında hesaplarında paylaşmıştır.

TikTok tüm dünyada olduğu gibi ülkemizde de oldukça popüler bir sosyal medya uygulamasıdır. TikTok popülerliğinin yanı sıra son yıllarda pek çok ülkede veri gizliliği ve ahlaki dejenerasyon başlıkları altında da sıkça eleştirilmektedir. Veri gizliliği noktasında ByteDance'nin daha şeffaf bir politika izlemesi belki kuşkuları bir nebze de olsa hafifletecektir fakat buradaki dejenerasyonun üstesinden gelmek adına kısıtlama ve yasaklamalardan ziyade kullanıcı odaklı bir yaklaşımın da benimsenmesi gerekir. Medya okur yazarlığı dersi ve topluma sosyal medya kullanımı noktasında verilecek eğitimlerle kullanıcılar TikTok'u daha bilinçli bir biçimde tüketebilir. 
TikTok'ta paylaşılan içeriklerin denetlenebilirliği kullanıcıların rapor etmesine bırakılmaktadır. İçerik sağlayıcı kullanıcı temelli bir yaklaşımın yanı sıra özellikle toplum sağlığı ve terör propagandası yapan hesaplara ilişkin TikTok'un kendisi de daha aktif bir rol oynamalıdır. Özellikle çocukların ve gençlerin psikolojik ve ahlaki dejenerasyonuna neden olabilecek içeriklerle karşılaşmasını engellemek adına TikTok tarafindan hesap silme veya ilgili kullanıcıyı engelleme noktasındaki adımlar hızlıca atımalıdır. Tüm bunların yanı sıra kurumun işlenen suç noktasında yasa koyucularla veri paylaşımı ve iş birliğine de gitmesi gerekir. TikTok dışında ebeveynlere de ciddi görevler düşmektedir. Anne ve babalar, TikTok uygulaması kullanan çocuklarının ne izlediğine, kimlerle iletişime geçtiğine ve hangi canlı yayınlara katıldığına dair bilgileri edinmelidir. Aksi takdirde; sonu ciddi yaralanmalara, ahlaki ve ruhsal bozukluklara, cinayet ve intihara varan süreçleri çocukları üzerinden deneyimleyebilirler

TikTok’un gençler üzerindeki etkisi farklı kültürler özelinde ortaya konulmuştur. Burada TikTok kullanıcılarının; kazara ölümler, intihar, bağımlılık, ruhsal bozukluklar, depresyon ve siber zorbalık gibi sorunlarla karşılaştğı tespit edilmiştir (Prabhjot, 2020, s. 4206). Fakat bu konuda Türkiye örneklemi çerçevesinde ulaşılan bir çalışmaya rastlanmamıştır. Bu noktada TikTok'un farklı sosyodemografik özelliklere sahip kişiler üzerindeki etkilerini inceleyen çalışmalar yapılmalıdır. Ayrıca TikTokerların neden bu mecrada içerik paylaştı̆ı ve bu içeriklerin izleyiciler tarafindan nasıl algılandığı veya yorumlandığı sorularını da referans alan çalışmaların yapılması konunun daha iyi kavranmasına katkı sağlayacaktır.

\section{Çıkar Çatışması Beyanı}

Makale yazarları herhangi bir çıkar çatışması olmadığını beyan etmiştir.

\section{Kaynakça}

Akpınar, M. E. (2021). TikTok akımlarının sosyal medyadaki eleştirisi: Twitter üzerinden yapılan eleştirilerin incelenmesi. 19 Mayıs Sosyal Bilimler Dergisi, 2(2), 363-381. doi:10.52835/19maysbd. 888628

Anderson, K. E. (2020). Getting acquainted with social networks and apps: It is time to talk. Library Hi Tech News, 37(4), 7-12. doi:10.1108/LHTN-01-2020-0001

Appannie. (2021). Top Apps on iOS, United States, Overall, September 21, 2021: https:// www.appannie.com/en/apps/ios/top/united-states/overall/iphone/ adresinden alındı (Erişim Tarihi: 21.09.2021).

Bangs, C. D. (2020). Tiktok stars. New York: Grosset \& Dunlap. 
Berelson, B. (1952). Content analysis in communication research. Glenco: Free Press.

Boffone, T. (2021). Renegades: Digital dance cultures from dubsmash to TikTok. UK: Oxford University Press.

Craig, D., Lin, J., \& Cunningham, S. (2021). Wanghong as social media entertainment in China. Switzerland: Palgrave Macmillan. doi:10.1007/978-3-030-65376-7

Creswell, J. (1998). Qualitative inquiry and research design: Choosing among five traditions. Thousand Oaks, CA: Sage.

Dalkey, N., \& Helmer, O. (1963). An experimental application of the Delphi method to the use of experts. INFORMS, 9(2), 458-467. https://www.jstor.org/stable/2627117 adresinden alındı (Erişim Tarihi: 26.09.2021).

Domingues, P., Nogueira, R., Francisco, J. C., \& Frade, M. (2020). Post-mortem digital forensic artifacts of TikTok Android App. (s. 1-18). Virtual Event: In Proceedings of the 15th International Conference on Availability, Reliability and Security, August 25-28 2020.

Donald, A. (1956). Content analysis in AV communication research. Audio Visual Communication Review, 4(2), 102-108. doi:10.2307/30216776

Etikan, I., Musa, S. A., \& Alkassim, R. S. (2016). Comparison of convenience sampling and purposive sampling. American Journal of Theoretical and Applied Statistics, 5(1), 1-4. doi:10.11648/j.ajtas.20160501.11

Gedikoğlu, E. ve Atalay, G. E. (2021). Çevrim içi disinhibisyon etkisi ile değişen normlar, aşınan değerler: Sosyal medya dilenciliği. Yeni Medya, 10, 107-136. https:// dergipark.org.tr/en/pub/yenimedya/issue/62586/925860 adresinden alındı (Erişim Tarihi: 29.09.2021).

George, A. L. (2003). "içcerik çözümlemesinde nicel ve nitel yaklaşımlar", iletişim araştırmalarında içerik çözümlemesi. (M. S. Çebi, Çev.) Ankara: Alternatif.

Gómez, A. R. (2019). Digital fame and fortune in the age of social media: A classification of s ocial media influencers. aDResearch: Revista Internacional de Investigación en, 19, 8-29. doi:10.7263/adresic-019-01

Google Trends. (2021). TikTok. https://trends.google.com.tr/trends/explore?da te $=2019-01-01 \% 202021-07-31 \& g e o=T R \& q=T i k T o k$ adresinden alındı (Erişim Tarihi: 05.10.2021).

HaberGlobal.(2021).TikTokfenomenicanlıyayındayaşamınasonverdi.https://haberglobal. com.tr/magazin/tiktok-fenomeni-canli-yayinda-yasamina-son-verdi-145883 adresinden alındı (Erişim Tarihi: 04.10.2021).

Hansen, A. (2000). "Içerik çözümlemesi”: Illetişim araştırmalarında içerik çözümlemesi. (M. S. Çebi, Çev.) Ankara: Alternatif.

Holsti, O. (1969). Content analysis for the social sciences and humanities. MA: Addison Wesley. 
Horowitz, J., \& Lorenz, T. (2021). Khaby Lame, the Everyman of the Internet. https://www. nytimes.com/2021/06/02/style/khaby-lame-tiktok.html adresinden alındı (Erişim Tarihi: 30.09.2021).

Hürriyet. (2021). Tiktok videosu çekiyorlardı... Düştü, öldü. https://www.hurriyet.com.tr/ gundem/tiktok-videosu-cekiyorlardi-dustu-oldu-41878357 adresinden alındı (Erişim Tarihi: 02.10.2021).

Jin, S. V., Muqaddam, A., \& Ryu, E. (2019). Instafamous and social media influencer marketing. Marketing Intelligence \& Planning, 37(5), 567-579. doi:10.1108/MIP09-2018-0375

Jordan, E., \& Javernick-WiLL, A. (2013). Indicators of community recovery: Content analysis and Delphi approach. Natural hazards review, 14(1), 21-28. doi:10.1061/ (ASCE)NH.1527-6996.0000087.

Kassarjian, H. H. (1977). Content analysis in consumer research. Journal of Consumer Research, 4(1), 8-18. https://www.jstor.org/stable/2488631 adresinden alındı (Erişim Tarihi: 07.10.2021).

Katz, R., Ogilvie, S., Shaw, J., \& Woodhead, L. (2021). Gen Z, Explained: The art of living in a digital age. Chicago: The University Chicago Press.

Kaye, D., Chen, X., \& Zeng, J. (2021). The co-evolution of two Chinese mobile short video apps: Parallel platformization of Douyin and TikTok. Mobile Media \& Communication, 9(2), 229-253. doi:10.1177/2050157920952120

Kennedy, M. (2020). 'If the rise of the TikTok dance and e-girl aesthetic has taught us anything, it's that teenage girls rule the Internet right now': TikTok celebrity, teenage girls and the Coronavirus crisis. European Journal of Cultural Studies, 6, 1069-1076. doi:10.1177/1367549420945341

Khattab, M. (2020). Synching and performing: Body (re)-presentation in the short video app TikTok. Wider Screen, 21(12). https://osuva.uwasa.fi/handle/10024/10471 adresinden alındı (Erişim Tarihi: 03.10.2021).

Kolbe, R. H., \& Burnett, M. S. (1991). Content-analysis research: An examination of applications with directives for improving research reliability and objectivity. Journal ofConsumer Research, 18(2), 243-250. doi:10.1086/209256

Kolomeets, M., \& Chechulin, A. (2021). Analysis of the malicious bots market (s. 19905). In 2021 29th Conference of Open Innovations Association (FRUCT) IEEE, Finland, 12-14 May 2021. doi:10.23919/FRUCT52173.2021.9435421.

Krippendorff, K. (1980). Validity in content analysis. Computerstrategien für die kommunikationsanalyse, 69-112. https://repository.upenn.edu/asc_papers/291/ adresinden alındı (Erişim Tarihi: 24.09.2021).

Krippendorff, K. (2004). Reliability in content analysis: Some common misconceptions and recommendations. Human Communication Research, 30(3), 411-433. doi:10.1111/j.1468-2958.2004.tb00738.x 
Li, R. (2018). The secret of internet celebrities: A qualitative study of online opinion leaders on Weibo (s. 533-542). Hawai: Proceedings of the 51st Hawaii International Conference on System Sciences.

Liqian, H. (2018). Study on the perceived popularity of Tik Tok. Bangkok University, Master of degree in Communication Arts.

Lodice, R., \& Papapicco, C. (2021). To be a TikToker in COVID-19 era: An experience of social influence. Online Journal of Communication and Media Technologies, 11(1), 1-12. doi:10.30935/ojcmt/9615

Lombard, M., Snyder-Dutch, J., \& Bracken, C. C. (2004). A call for standardization in content analysis reliability. Human Communication Research, 30(3), 434-437. doi:10.1111/j.1468-2958.2004.tb00739.x

Lord, W., Heim, T., Stevenson, R., \& Schofield, L. (2019). A parent's guide to TikTok (Axis Parent's Guide). Colorado: David C Cook.

Lutfiah, S., \& Sudarwati, E. (2021). "Jargon used on TikTok check...": Language variation revisited. Jurnal Kata, 5(2), 359-371.

Ma, L., Feng, J., Feng, Z., \& Wang, L. (2019). Research on user loyalty of short video app based on perceived value - Take Tik Tok as an example. (s. 1-6). Shenzhen, China: 16th International Conference on Service Systems and Service Management (ICSSSM), 13-15 July 2019.

Masanet, M. J., Márquez, I., Pires, F., \& Lanzeni, D. (2020). Teens and digital image creation on social media: Informal learning, transmedia skills and professional profiles. BID, 45. doi:10.1344/BiD2020.45.11

Miller, D. (2020). Social media marketing 3 Books in One: Excellent tricks to grow your business, Instagram marketing to become a famous influencer, Tiktok \& YouTube Marketing to create viral videos. Independently Published.

Neuendorf, K. (2012). The content analysis guidebook (2. Ed.). California: Sage.

Neyaz, A., Kumar, A., Krishnan, S., Placker, J., \& Liu, Q. (2020). Security, privacy and steganographic analysis of FaceApp and TikTok. International Journal of Computer Science and Security (IJCSS), 14 (2), 38-59.

Omar, B., \& Dequan, W. (2020). Watch, share or create: The influence of personality traits and user motivation. International Journal of Interactive Mobile Technologies, 14(4), 121-137. doi:10.3991/ijim.v14i04.12429

Prabhjot, K. (2020). Tik-Tok: Influence on youth in India. Palarch's Journal of Archaeology of Egypt/Egyptology, 17(6), 4194-4207. https://archives.palarch.nl/index.php/ jae/article/view/1658 adresinden alındı (Erişim Tarihi: 19.09.2021).

Qiyang, Z., \& Heekyoung, J. (2019). Learning and sharing creative skills with short videos: A case study of user behavior in TikTok and Bilibili. M. Evans, A. Shaw, \& J. Na (Ed), Design revolutions: IASDR 2019 Conference Proceedings içinde (s. 114128). Manchester: Manchester Metropolitan University. 
Riffe, D., Lacy, S., Watson, B. R., \& Fico, F. (2019). Analyzing media messages using quantitative content analysis in research (Fourth edition). New York: Routladge.

Schellewald, A. (2021). Communicative forms on TikTok: Perspectives from digital ethnography. International Journal of Communication, 15, 14371457. https://ijoc.org/index.php/ijoc/article/view/16414/3389 adresinden alındı (Erişim Tarihi: 26.08.2021).

Scherr, S., \& Wang, K. (2021). Explaining the success of social media with gratification niches: Motivations behind daytime, nighttime, and active use of TikTok in China. Computers in Human Behavior, 124, 19. doi:10.1016/j.chb.2021.106893

Schreier, M. (2012). Qualitative content analysis in practice. London: Sage publications.

Segev, H. (2020). The ban on TikTok: The US struggle against China spreads to apps. INSS Insight. https://www.inss.org.il/wp-content/uploads/2020/08/no.-1372.pdf adresinden alındı (Erişim Tarihi: 16.08.2021).

Senft, T. M. (2008). Camgirls: Celebrity and community in the age of social networks. New York: Peter Lang.

Serrano, J. M., Papkyriakopoulos, O., \& Hegelich, S. (2020). Dancing to the partisan beat: A first analysis of political communication on TikTok. 12th ACM Conference on Web Science, Online Conference. Southampton. https://arxiv.org/abs/2004.05478 adresinden alındı (Erişim Tarihi: 10.08.2021).

Sezer, N. ve Özcan, Z. (2021). Yeni bir sınıflandırma çalışması olarak sosyal medya fenomenlerinin paylaşımda bulundukları içerik türlerine göre sınıflandırılması: YouTube örneği. İletişim Çalışmaları Dergisi, 7(1), 109-136. doi:10.17932/IAU.ICD.2015.006/icd_v07i1005

Shengjie, J. (2021). Tiktok analysis. Journal of Frontiers of Society, Science and Technology, 1(1), 8-12. doi:10.23977/jfsst.2021.010103

Siddiqui, A. (2021). Viral videos and their impact on society. Journal of SocioEconomic and Religious Studies, 1(2), 1-10. doi:10.52337/jsers.v1i2.25

Stay, J. (2021). TikTok $^{\circledR}$ for Dummies ${ }^{\circledR}$. Canada: John Wiley \& Sons.

Subramanian, S. (2021). Bahujan girls' anti-caste activism on TikTok. Feminist 
Media Studies, 21(1), 154-156. doi:10.1080/14680777.2021.1864875

Sun, L., Zhang, H., Zhang, S., \& Luo, J. (2020). Content-based Analysis of the Cultural Differences between TikTok and Douyin (s. 4779-4786). IEEE In ternational Conference on Big Data, doi:10.1109/BigData50022. 2020.9378032

Supak, G. (2021). Political posturing or a move towards "Net Nationalism?": The legality of a TikTok ban and why foreign tech companies should be paying attention. North Carolina Journal of Law \& Technology, 22(3), 527-572.

Şeker, A. (2021). Dijital pazarlamanın yükselen gücü: Tiktok ve Twitch. C. TorKadıoğlu (Ed.), Dijital Pazarlamada Güncel Araştırmalar içinde (s. 45-70). İstanbul: Karadeniz Kitap.

Tam, M. S. (2020). Sosyal medya etkileyicilerinin kanaat önderliği rolü. Gümüşhane Üniversitesi İletişim Fakültesi Elektronik Dergisi, 8(2), 1325-1351. doi:10.19145/e-gifder.726057

TikTok. (2021). Görevimiz. https://www.tiktok.com/about?lang=tr-TR adresinden alındı (Erişim Tarihi: 24.08.2021).

TRT Haber. (2021). Sosyal medya devleri Türkiye temsilcilerini atadı. https:// www.trthaber.com/haber/ekonomi/sosyal-medya-devleri-turkiyetemsilcilerini-atadi-566084.html adresinden alındı (Erişim Tarihi: 15.08.2021).

Uğurhan, Y. Z. ve Yaşar, İ. H. (2021). Tiktok'taki reklam ve sponsorlu içeriklerin satın alma niyeti üzerindeki rolü: Sosyo-demografik değişkenler özelinde bir inceleme. Abant Sosyal Bilimler Dergisi, 21(2), 243-269. doi:10.11616/ basbed.

Unni, Z., \& Weinstein, E. (2021). Shelter in place, connect online: Trending TikTok content during the early days of the US COVID-19 pandemic. Journal of Adolescent Health, 68(5), 863-868. doi:10.1016/j.jadohea Ith.2021.02.012

Vizcaíno-Verdú, A., \& Tirocchi, S. (2021). Tiktokers y objetivación sexual de género en retos musicales. Media Education, 12(1), 7-16. doi:10.36253/ me-9674

Wang, Y. (2020). Humor and camera view on mobile short-form video apps influence user experience and technology-adoption intent, an example 
of TikTok (DouYin). Computers in Human Behavior, 110, 1-9. doi:10.1016/j.chb.2020.106373 wearesocial. (2021).

Digital 2021 Global Overview Report. Hootsuite. https:// wearesocial.com/digital-2021 adresinden alındı (Erişim Tarihi: 15.08.2021).

Weimann, G., \& Masri, N. (2020). Research note: Spreading hate on TikTok. Studies in Conflict \& Terrorism, Online First, 1-14. doi:10.1080/ 1057610X.2020.1780027

White, M. D., \& Marsh, E. E. (2006). Content analysis: A flexible methodology. Library trends, 55(1), 22-45.

Yang, S., Zhao, Y., \& Ma, Y. (2019). Analysis of the reasons and development of short video application - Taking Tik Tok as an example. 9th International Conference on Information and Social Science (ICISS 2019), (s. 340-343). Manila, Philippines. doi:10.25236/iciss.2019.062

Yıldız, Ö. (2019). Herkes için kültürel üretïm: Türkïye'de Tiktok uygulamasi örneği. A. Kuşçulu ve E. Gurbanov (Ed.), II. Uluslararası Sosyal Bilimler Kongresi içinde, (s. 619-632). Nevşehir. http://www.usbik.com/?pnum=252\&pt= USBIK+2018+B\%C4\%BOldiri+Tam+Metin+Kitab\%C4\%B1\%2F+Book+of+ Full+Text++ adresinden alındı (Erişim Tarihi: 07.08.2021).

Yiming, Z. (2020). bpntoday. On the Dangers of the Meteoric Rise and Ban of TikTok: https://www.bpntoday.com/politics-1/on-the-dangers-of-themeteoric-rise-and-ban-of-tiktok adresinden alındı (Erişim Tarihi: 05.08.2021).

Zeng, J., Abidin, C., \& Schafer, M. S. (2021). Research perspectives on TikTok and its legacy apps: Introduction. International Journal of Communication, 15, 3161-3172. doi:10.5167/uzh-205427

Zhang, Z. (2020). Infrastructuralization of Tik Tok: Transformation, power relati onships, and platformization of video entertainment in China. Media, Culture \& Society, 43(2), 219-236. doi:10.5334/csci.140

\section{TikTok Video Kaynakça}

aydas, (01.08-31.08.2021).https://www.tiktok.com/@aydas cellat36, (01.08-31.08.2021).https://www.tiktok.com/@cellat36 
cemresolmaz, (01.08-31.08.2021). https://www.tiktok.com/@cemresolmaz cerenyaldz, (01.08-31.08.2021). https://www.tiktok.com/@cerenyaldz cilgindoncurmaci_. (01.08-31.08.2021).https://www.tiktok.com/@cilgindondurmaci_

cznburak. (01.08-31.08.2021). https://www.tiktok.com/@cznburak korayzeynep, (01.08-31.08.2021). https://www.tiktok.com/@korayzeynep nnursema, (01.08-31.08.2021). https://www.tiktok.com/@nnursema nusr_et, (01.08-31.08.2021). https://www.tiktok.com/@nusr_et yesimresmi1, (01.08-31.08.2021). https://www.tiktok.com/@yesimresmi1 